\title{
Description of Anaerobaculum hydrogeniformans sp. nov., an anaerobe that produces hydrogen from glucose, and emended description of the genus Anaerobaculum
}

\author{
Matthew W. Maune and Ralph S. Tanner
}

Correspondence

Ralph S. Tanner

rtanner@ou.edu

\author{
Department of Botany and Microbiology, University of Oklahoma, Norman, OK 73019, USA
}

The bacterial phylum Synergistetes is an under-represented phylogenetic cluster of Gram-negative, anaerobic, rodshaped bacteria that are related to Synergistes jonesii (Jumas-Bilak et al., 2009). Members of this group have been isolated from a variety of environments including anaerobic digesters (LaPara et al., 2000; Wu et al., 2001), the termite hindgut (Ohkuma \& Kudo, 1996), subgingival plaque (Munson et al., 2004) and petroleum reservoirs (Orphan et al., 2000; van der Kraan et al., 2010; Voordouw et al., 1996). The species in this group with validly published names display diverse physiological properties, but all currently cultivated strains catabolize amino acids (Jumas-Bilak et al.,

Abbreviation: FAME, fatty acid methyl ester.

The GenBank/EMBL/DDBJ accession number for the 16S rRNA gene sequence of strain $\mathrm{OS}^{\top}{ }^{\top}$ is FJ862996.

A supplementary figure and a supplementary table are available with the online version of this paper.
2009; Vartoukian et al., 2007). It has been noted that these organisms, although underrepresented amongst cultivated taxa, are not uncultivable but are present at low cell numbers in microbial communities (Godon et al., 2005). The genus Anaerobaculum, comprising Anaerobaculum thermoterrenum (Rees et al., 1997) and Anaerobaculum mobile (Menes \& Muxí, 2002), is a member of the phylum Synergistetes, but the ability of Anaerobaculum species to catabolize amino acids has not been studied. However, their capacity to produce hydrogen gas from sugars has been documented (Menes \& Muxí, 2002).

Increasing global demand for fossil fuels and a need to decrease carbon dioxide emissions have driven research towards renewable, carbon-neutral energy sources. Hydrogen has the potential to be a sustainable alternative to some fossil fuels. It is a clean fuel that burns with no carbon dioxide emissions and the energy released can be easily converted to electricity by fuel cells (Davila-Vazquez 
et al., 2008). Hydrogen has an energy yield of $122 \mathrm{~kJ} \mathrm{~g}^{-1}$, which is 2.75 times greater than that of hydrocarbon-derived fuels (Kapdan \& Kargi, 2006). Presently, about $95 \%$ of the world's hydrogen is produced via steam reformation of natural gas, which does not lower net carbon dioxide emissions, and is resource- and energy-intensive (Lee et al., 2008). The production of hydrogen from renewable resources such as biomass or waste materials is being explored as a sustainable global fuel source. 'Darkfermentative' bacteria can produce hydrogen from carbohydrates and other waste products (Angenent et al., 2004; Han \& Shin, 2004; Li \& Fang, 2007) without the need for light input (Nandi \& Sengupta, 1998), according to the equation

$\mathrm{C}_{6} \mathrm{H}_{12} \mathrm{O}_{6}+4 \mathrm{H}_{2} \mathrm{O} \rightarrow 4 \mathrm{H}_{2}+2 \mathrm{CH}_{3} \mathrm{COO}^{-}+2 \mathrm{HCO}_{3}^{-}+4 \mathrm{H}^{+}$ $\left(\Delta \mathrm{G}^{0^{\prime}}=-206.3 \mathrm{~kJ} \mathrm{~mol}^{-1}\right)$.

The Gibbs' free energy of formation given above was taken from Thauer et al. (1977), and is essentially the same as that given by Kengen et al. (2009).

Four hydrogen molecules can be produced per D-glucose molecule via this thermodynamically favourable reaction, with acetate and carbon dioxide as additional products. However, only a handful of organisms have been isolated that produce amounts of hydrogen close to this, such as Acetomicrobium faecalis (Winter et al., 1987), Anaerobaculum mobile (Menes \& Muxí, 2002), Caldicellulosiruptor saccharolyticus (van Niel et al., 2002), Thermotoga maritima (Schröder et al., 1994) and Thermotoga elfii (van Niel et al., 2002). An objective of the United States Department of Energy is exploration of novel biological catalysts that can produce four hydrogen molecules per molecule of glucose (US Department of Energy, 2007).

The hydrogen-producing bacterium strain $\mathrm{OS}^{\mathrm{T}}$ isolated from oil production water is described in this study. On the basis of phenotypic and genotypic evidence, strain $\mathrm{OS}^{\mathrm{T}}$ is proposed to represent a new species of the genus Anaerobaculum. The description of the genus is also emended to include the amino acids catabolized by the three species reported to date. Strain $\mathrm{OS}^{\mathrm{T}}$ can produce almost four hydrogen molecules per molecule of D-glucose, which approaches the theoretical maximum via the aforementioned reaction. It also has the ability to produce hydrogen from a variety of amino acids and other organic acids.

Strain $O S 1^{\mathrm{T}}$ was isolated from oil production water collected from Alaska, USA, as part of a study of the microbiology of a North Slope oil facility (Duncan et al., 2009). A most probable number (MPN) enumeration of general heterotrophs was conducted at $50{ }^{\circ} \mathrm{C}$ using anaerobic half-strength tryptic soy broth (TSB; Difco) with $1 \% \mathrm{NaCl}$ and $100 \%$ nitrogen gas phase (Balch \& Wolfe, 1976). Strain OS1 ${ }^{\mathrm{T}}$ was the dominant culturable heterotroph, present in the production water at 2.3 cells $\mathrm{ml}^{-1}$ (MPN). The dominant culturable hydrogen oxidizer, Methanothermobacter thermautotrophicus, was present at the same cell density (Duncan et al., 2009). The Hungate agar roll-tube method was used for isolation (Hungate, 1969). Colonies on anaerobic roll tubes were small, circular, smooth and yellowish in colour. Exponential-phase cells grown on D-glucose were used for transmission electron microscopy. Cells were fixed with $1 \%$ glutaraldehyde, spread onto carbon-coated Formvar grids and stained with $0.5 \%$ phosphotungstate $(\mathrm{pH} 7.0)$. Cells were photographed using a JEOL JEM 2000 FX transmission electron microscope. Cells were Gram-negative, non-flagellated, non-motile, non-spore-forming rods, $1.7-2.7 \times 0.4-$ $0.5 \mu \mathrm{m}$, that occurred singly (see Fig. S1, available in IJSEM Online).

Strain $\mathrm{OS}^{\mathrm{T}}$ was cultivated routinely at $55{ }^{\circ} \mathrm{C}$ on anaerobic TSB plus $1 \% \mathrm{NaCl}$. Cells grown under these conditions can be lyophilized for long-term preservation, provided adequate attention is given to the maintenance of anaerobic conditions. The temperature and $\mathrm{NaCl}$ range and optima were determined using TSB as the growth medium. Growth (optical density) was measured spectrophotometrically at $600 \mathrm{~nm}$ using a Spectronic 20D (Thermo Spectronic). Strain $\mathrm{OS}^{\mathrm{T}}$ grew optimally at $55{ }^{\circ} \mathrm{C}$ (range $40-65{ }^{\circ} \mathrm{C}$ ) with $1 \%$ $\mathrm{NaCl}$ (range $0.8-7 \%$ ). For determination of the $\mathrm{pH}$ range and optimum, TSB was amended with the following buffers (at $10 \mathrm{~g} \mathrm{l}^{-1}$ ): HOMOPIPES, $\mathrm{pH} 4$ and 5; MES, $\mathrm{pH} 6$ and 6.5; TES, $\mathrm{pH} 7$ and 7.5; TAPSO, $\mathrm{pH} 8$; TAPS, $\mathrm{pH} 8.5$; CAPSO, $\mathrm{pH} 9$ and 9.5 (Tanner, 2007). The final $\mathrm{pH}$ was adjusted at $55{ }^{\circ} \mathrm{C}$. Strain $\mathrm{OS}^{\mathrm{T}}$ grew optimally at $\mathrm{pH} 7.5$ (range pH 6-9). A mineral medium was developed for routine growth, containing $\left(1^{-1}\right) 10 \mathrm{ml}$ mineral solution (Tanner, 2007), $10 \mathrm{ml}$ vitamin solution (Tanner, 2007), $10 \mathrm{ml}$ trace metal solution (Tanner, 2007), $10 \mathrm{~g} \mathrm{NaCl}, 2 \mathrm{~g}$ yeast extract (Difco) and $3 \mathrm{~g}$ D-glucose. The medium was buffered with $10 \mathrm{~g}$ TES at $\mathrm{pH}$ 7.5. The medium was prepared using strict anaerobic technique under a final gas phase of $100 \%$ nitrogen (Balch \& Wolfe, 1976).

Nitrate reduction and sulfide production were measured using CHEMetrics test kits (CHEMetrics, Inc). Nitrate, Lcystine, sulfate, thiosulfate and sulfite were added to the medium from sterile stock solutions. Elemental sulfur was added and sterilized as described previously (Rees et al., 1997). Crotonate reduction was measured by HPLC using a Shimadzu LC-20AT with an SPD-20A UV/Vis detector equipped with an Aminex HPX-87H ion exclusion column (Bio-Rad) using $0.001 \mathrm{M} \mathrm{H}_{2} \mathrm{SO}_{4}$ as the mobile phase at a flow rate of $0.9 \mathrm{ml} \mathrm{min}^{-1}$. Strain OS1 ${ }^{\mathrm{T}}$ reduced elemental sulfur, thiosulfate and L-cystine to sulfide when grown in anaerobic TSB plus $1 \% \mathrm{NaCl}$. Nitrate, sulfite and sulfate reduction were not observed. Strain $\mathrm{OS}^{\mathrm{T}}{ }^{\mathrm{T}}$ reduced crotonate to butyrate in the presence of glucose but did not ferment crotonate alone. Sulfur and thiosulfate reduction, as well as crotonate reduction in the presence of D-glucose, seems to be a universal phenotype of the genus Anaerobaculum (Menes \& Muxí, 2002; Rees et al., 1997).

Genomic DNA was isolated from strain $\mathrm{OS1}^{\mathrm{T}}$ using a modification of the Marmur procedure (Johnson, 1994). The $\mathrm{G}+\mathrm{C}$ content of the genomic DNA was measured by HPLC, as described previously (Mesbah et al., 1989), with modifications described previously (Allen et al., 2008). 16S 
rRNA gene sequencing was conducted using DNA as a template for PCR amplification using the universal primers 27f, 357f, 704f, 926f, 907r and 1492r corresponding to the Escherichia coli numbering system (Johnson, 1994). Sequencing was performed by the Oklahoma Medical Research Foundation (Oklahoma City, OK, USA). Primer sequences were aligned using the Sequencher software suite (Gene Codes Corporation), which resulted in a 1444-base contiguous DNA sequence. The phylogenetic position of strain $\mathrm{OS}^{\mathrm{T}}$ was assessed via maximum-likelihood analysis (Olsen et al., 1994). A consensus tree was generated by bootstrapping at values greater than $90 \%$ confidence (Felsenstein, 1985) (Fig. 1). The topology and major branching points of the phylogenetic tree were confirmed by neighbour-joining and maximum-parsimony analyses in the ARB software suite (Ludwig et al., 2004) (not shown).

$16 \mathrm{~S}$ rRNA gene sequence analysis indicated that strain OS1 ${ }^{\mathrm{T}}$ was a member of the genus Anaerobaculum (Fig. 1). A. thermoterrenum and A. mobile are currently the two described members of this genus (Menes \& Muxí, 2002; Rees et al., 1997), which are members of the phylum Synergistetes (Hugenholtz et al., 2009; Vartoukian et al., 2007). The $16 \mathrm{~S}$ rRNA gene of strain OS1 $1^{\mathrm{T}}$ was $99.7 \%$ similar to that of the type strain of A. thermoterrenum and $97.8 \%$ similar to that of the type strain of A. mobile. It may not be surprising to find a close relative to $A$. thermoterrenum in oil production water, because the type strain of this species was isolated from a similar environment (Rees et al., 1997). Culture-independent surveys have shown the presence of Anaerobaculum strains in petroleum reservoirs (GenBank accession numbers GU357467 and EU573105) (Gieg et al., 2010; Kaster et al., 2009), mining wastewater (DQ256300) (Gihring et al., 2006), a solid waste digestor (EF559029) (Li et al., 2009) and methanogenic reactors (AB234001, FN563242, FN563270 and AB274508) (Krakat et al., 2011; Sasaki et al., 2006, 2007). A. mobile was isolated from an anaerobic wastewater treatment lagoon (Menes \& Muxí, 2002). This suggests that strains of Anaerobaculum may be present in many anaerobic environments, particularly thermophilic ones. The $\mathrm{G}+\mathrm{C}$ content of the genomic DNA from strain $\mathrm{OS1}^{\mathrm{T}}$ was $46.6 \mathrm{~mol} \%$, compared with $44 \mathrm{~mol} \%$ for A. thermoterrenum (Rees et al., 1997) and $51.5 \mathrm{~mol} \%$ for A. mobile (Menes \& Muxí, 2002).
DNA-DNA reassociation analysis was necessary for taxonomic placement of strain $\mathrm{OS}^{\mathrm{T}}$, and was conducted in the laboratory of Dr Peter Schumann at the Deutsche Sammlung von Mikroorganismen und Zellkulturen GmbH (DSMZ) as described by De Ley et al. (1970), with the modifications described by Escara \& Hutton (1980) and Huß et al. (1983). Analysis was performed using a model 2600 spectrophotometer equipped with a model 2257-R thermoprogrammer and plotter (Gilford Instrument Laboratories). Rates of renaturation were computed with the program TRANSFER.BAS (Jahnke, 1992). A DNA-DNA reassociation value of $68 \pm 4 \%$ was observed when strain $\mathrm{OS1}^{\mathrm{T}}$ was hybridized to A. thermoterrenum DSM $13490^{\mathrm{T}}$, which is close to the threshold value of $70 \%$ for the definition of species (Stackebrandt \& Ebers, 2006), suggesting that strain OS1 $^{\mathrm{T}}$ may belong to a species distinct from $A$. thermoterrenum.

A. thermoterrenum DSM $13490^{\mathrm{T}}$ and A. mobile DSM $13181^{\mathrm{T}}$ were obtained from the DSMZ and used in characterization assays. The basal medium used for routine growth of these strains was the mineral medium described above. Growth experiments were conducted in triplicate. All substrates were added from sterile anaerobic stock solutions to a final concentration of $3 \mathrm{~g} \mathrm{l}^{-1}$ before inoculation. D-Glucosegrown cells were used as the inoculum for substrate tests. Growth and end-product formation were compared with substrate-unamended controls. Chemicals used in this work were obtained from Sigma-Aldrich unless otherwise noted. Growth was measured spectrophotometrically at $600 \mathrm{~nm}$ (Spectronic 20D) (Balch \& Wolfe, 1976). Phenotypic characteristics of strain $\mathrm{OS}^{\mathrm{T}}$ are listed in the species description and in Table 1 . Several of these substrates were not tested in the original descriptions of A. thermoterrenum (Rees et al., 1997) and A. mobile (Menes \& Muxí, 2002), nor was the ability to utilize amino acids as substrates, a characteristic of members of the phylum Synergistetes (Vartoukian et al., 2007). The list of substrates examined for the genus Anaerobaculum, as well as a comparison of the phenotypes of $A$. thermoterrenum DSM $13490^{\mathrm{T}}$, A. mobile DSM $13181^{\mathrm{T}}$ and strain $\mathrm{OS}^{\mathrm{T}}$, is given in Table 1.

As shown in Table 1, strain $\mathrm{OS}^{\mathrm{T}}$ can be readily differentiated from species of Anaerobaculum by several phenotypic characteristics, such as the ability to utilize malonate, maltose and inulin and the inability to catabolize

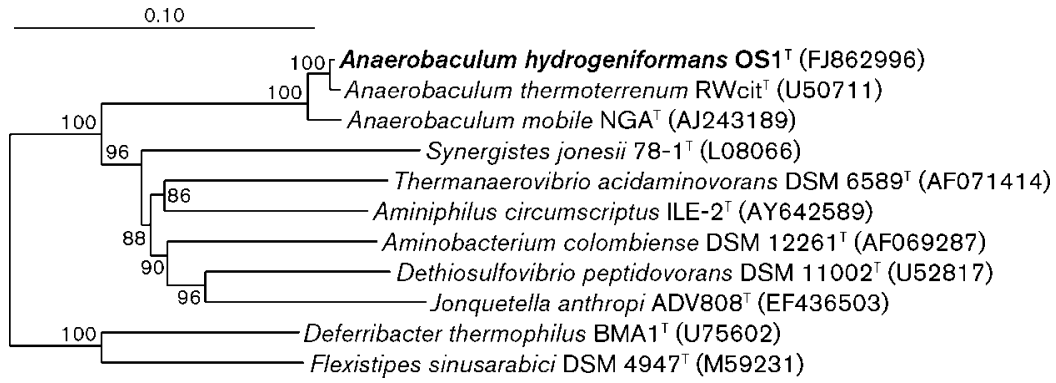

Fig. 1. Phylogenetic tree based on $16 \mathrm{~S}$ rRNA gene sequence analysis of strain $\mathrm{OS}^{\top}$ (Anaerobaculum hydrogeniformans sp. nov.) and other closely related micro-organisms within the phylum Synergistetes. Identical branches were present in phylogenetic consensus trees generated by the neighbour-joining, maximumlikelihood and maximum-parsimony algorithms. Bootstrap values are expressed as percentages of 1000 replications. Bar, 1 substitution per 10 nucleotide positions. 
Table 1. Phenotypic comparison of $A$. hydrogeniformans $\mathrm{sp}$. nov. $\mathrm{OS}^{\top}{ }^{\top}, A$. thermoterrenum DSM $13490^{\top}$ and $A$. mobile DSM $13181^{\top}$

Strains: 1 , A. hydrogeniformans sp. nov. $\mathrm{OS}^{\mathrm{T}} ; 2$, A. thermoterrenum DSM $13490^{\mathrm{T}} ; 3$, A. mobile DSM $13181^{\mathrm{T}}$. Data were obtained in this study unless indicated. All three strains utilized D-fructose, D-glucose, pyruvate, L-tartrate, Casamino acids, L-asparagine, L-cysteine, Lhistidine, L-serine, L-threonine and L-valine. All three strains did not utilize D-arabinose, cellobiose, cellulose, D-galactose, lactose, melibiose, raffinose, D-rhamnose, sucrose, D-xylose, dextrin, xylan, adonitol, acetate, butyrate, L-aspartate, L-glutamine, glycine, L-lysine, L-methionine, L-proline, L-tryptophan or L-tyrosine.

\begin{tabular}{|c|c|c|c|}
\hline Characteristic & 1 & 2 & 3 \\
\hline Growth rate $\left(\mathrm{h}^{-1}\right)$ & 0.011 & 0.013 & 0.010 \\
\hline \multicolumn{4}{|l|}{ Temperature for growth $\left({ }^{\circ} \mathrm{C}\right)$} \\
\hline Range & $40-65$ & $28-60$ & $35-65$ \\
\hline Optimum & 55 & 55 & $55-60$ \\
\hline \multicolumn{4}{|l|}{$\mathrm{pH}$ for growth } \\
\hline Range & $6.0-9.0$ & $5.5-8.6$ & $5.4-8.7$ \\
\hline Optimum & 7.0 & $7.0-7.6$ & $6.6-7.3$ \\
\hline \multicolumn{4}{|c|}{$\mathrm{NaCl}$ concentration for growth $\left(\mathrm{g} \mathrm{l}^{-1}\right)$} \\
\hline Range & $0.8-70$ & $0-20$ & $0-15$ \\
\hline Optimum & 10 & 10 & 0.08 \\
\hline DNA G $+\mathrm{C}$ content $(\mathrm{mol} \%)$ & 46.6 & $44^{a_{\star}}$ & $51.5^{b}$ \\
\hline Motility & - & - & + \\
\hline \multicolumn{4}{|l|}{ Growth on: } \\
\hline$\alpha$-Ketoglutarate & + & + & - \\
\hline Citrate & - & + & - \\
\hline Fumarate & - & + & - \\
\hline D-Gluconate & - & - & + \\
\hline L-Glutamate & + & + & - \\
\hline Lactate & - & + & - \\
\hline L-Malate & - & + & + \\
\hline Malonate & + & - & - \\
\hline Maltose & + & - & - \\
\hline D-Mannose & + & + & - \\
\hline Glycerol & - & + & + \\
\hline Inositol & + & + & - \\
\hline Tryptone & + & - & + \\
\hline L-Arginine & - & - & + \\
\hline L-Leucine & + & - & + \\
\hline L-Phenylalanine & + & - & + \\
\hline Inulin & + & - & - \\
\hline Pectin & - & + & - \\
\hline Starch & - & + & + \\
\hline
\end{tabular}

${ }^{\star}$ Data taken from: $a$, Rees et al. (1997); b, Menes \& Muxí (2002).

L-malate, glycerol and starch. Strain $\mathrm{OS}^{\mathrm{T}}$ had an absolute requirement for $\mathrm{NaCl}$ for growth, which the other two species do not share. In addition, strain $\mathrm{OS}^{\mathrm{T}}$ grew in medium containing up to $7 \% \mathrm{NaCl}$, which is much higher than the maxima of 2.0 and $1.5 \%$ observed for cultures of A. thermoterrenum (Rees et al., 1997) and A. mobile (Menes \& Muxí, 2002), respectively.
Cellular fatty acid methyl ester (FAME) and polar lipid analyses were conducted on strain $\mathrm{OS}^{\mathrm{T}}$, A. thermoterrenum DSM $13490^{\mathrm{T}}$ and A. mobile DSM $13181^{\mathrm{T}}$. Cells were grown at $55{ }^{\circ} \mathrm{C}$ in anaerobic TSB supplemented with $1 \% \mathrm{NaCl}$ containing a $100 \%$ nitrogen gas phase. FAME and polar lipid analyses were carried out by the Identification Service of the DSMZ and Dr B. J. Tindall (DSMZ). The fatty acid profiles for all three strains are shown in Table 2. FAME analysis showed that all three strains contained iso- $\mathrm{C}_{15: 0}$ and iso- $\mathrm{C}_{11: 0}$, with iso- $\mathrm{C}_{15: 0}$ as the predominant fatty acid. Strain $\mathrm{OS1}^{\mathrm{T}}$ contained both iso- $\mathrm{C}_{13: 0}$ and iso- $\mathrm{C}_{13: 0} 3-\mathrm{OH}$. However, A. thermoterrenum DSM $13490^{\mathrm{T}}$ did not have iso$\mathrm{C}_{13: 0} 3-\mathrm{OH}$ and A. mobile DSM $13181^{\mathrm{T}}$ did not have iso$\mathrm{C}_{13: 0}$. Polar lipid analysis results are summarized in Table S1. Polar lipid analysis showed that all three strains contained diphosphatidylglycerol, phosphatidylglycerol, phosphatidylethanolamine, three unknown phospholipids (PL1-PL3) and four unknown aminophospholipids (PN1PN4). Strain $\mathrm{OS1}^{\mathrm{T}}$ and A. thermoterrenum DSM $13490^{\mathrm{T}}$ were shown to contain phospholipids PL4 and PL5, but these were not detected in A. mobile DSM $13181^{\mathrm{T}}$.

Both A. thermoterrenum and A. mobile produced hydrogen, acetate and carbon dioxide when grown in pure culture on D-glucose. A. mobile was shown to grow syntrophically with a methanogen using D-glucose as the substrate (Menes \& Muxí, 2002). Syntrophic studies were conducted using strain $\mathrm{OS}^{\mathrm{T}}$ and the hydrogen-oxidizing methanogen $M$. thermautotrophicus DSM $1053^{\mathrm{T}}$. The syntrophic medium was the mineral medium described above, but $3 \mathrm{~g} \mathrm{NaHCO}_{3}$ was added after adjustment to $\mathrm{pH}$ 7.5. All syntrophic and pure-culture fermentation studies were carried out in $160 \mathrm{ml}$ crimp-sealed serum bottles with $10 \mathrm{ml}$ medium at $55{ }^{\circ} \mathrm{C}$ with D-glucose $\left(3 \mathrm{~g} \mathrm{l}^{-1}\right)$ as the substrate. Acetate was measured with a Shimadzu GC-8A equipped with a flameionization detector and a $2 \mathrm{~m}$ glass column packed with an 80/120 Carbopak B-DA/4 \% Carbowax resin 20M (Supelco) with helium as the carrier gas at a flow rate of $35 \mathrm{ml} \mathrm{min}^{-1}$. Methane, carbon dioxide and hydrogen were measured with a Shimadzu GC-8A GC equipped with a thermal conductivity detector and a Porapak Q ( 2 m stainless steel) column

Table 2. Cellular fatty acid compositions of $A$. hydrogeniformans $\mathrm{OS}^{\top}{ }^{\top}, A$. thermoterrenum DSM $13490^{\top}$ and $A$. mobile DSM $13181^{\top}$

Strains: 1, A. hydrogeniformans sp. nov. $\mathrm{OS}^{\mathrm{T}} ; 2$, A. thermoterrenum DSM $13490^{\mathrm{T}} ; 3$, A. mobile DSM $13181^{\mathrm{T}}$. Data were obtained in this study. Values are percentages of total identified fatty acids. ND, Not detected.

\begin{tabular}{|lccc|}
\hline Fatty acid & $\mathbf{1}$ & $\mathbf{2}$ & $\mathbf{3}$ \\
\hline iso- $\mathrm{C}_{11: 0}$ & 4.4 & 13.0 & 20.7 \\
iso- $_{13: 0}$ & 1.8 & 21.0 & $\mathrm{ND}$ \\
iso- $_{13: 0}$ 3-OH & 3.3 & $\mathrm{ND}$ & 8.5 \\
iso- $_{15: 0}$ & 90.5 & 66.1 & 70.7 \\
\hline
\end{tabular}


(Alltech) using nitrogen as the carrier gas at a flow rate of $30 \mathrm{ml} \mathrm{min}^{-1}$. Results from the pure and co-culture work are presented in Table 3. Strain OS1 ${ }^{\mathrm{T}}$, A. thermoterrenum DSM $13490^{\mathrm{T}}$ and $A$. mobile DSM $13181^{\mathrm{T}}$ all produced close to four hydrogen molecules per molecule of D-glucose and one molecule of methane per molecule of D-glucose when grown syntrophically with a hydrogen-oxidizing methanogen. In pure culture, strain $\mathrm{OS}^{\mathrm{T}}$ produced up to $3.1-4.5 \mathrm{mmol}$ hydrogen (l culture $)^{-1}$ using clarified raw sewage as the substrate (Maune \& Tanner, 2008).

On the basis of the genotypic and phenotypic data presented, strain $\mathrm{OS}^{\mathrm{T}}$ is proposed to represent a novel species of the genus Anaerobaculum, for which the name Anaerobaculum hydrogeniformans sp. nov. is proposed.

\section{Emended description of the genus Anaerobaculum Rees et al. 1997 emend. Menes and Muxí 2002}

Chemo-organotrophic, Gram-negative anaerobes. Moderately thermophilic $\left(28-65{ }^{\circ} \mathrm{C}\right)$ and halotolerant to halophilic (0-70 $\left.\mathrm{g} \mathrm{NaCl} \mathrm{l}^{-1}\right)$. Straight to slightly curved rods. Motile by means of a single flagellum or non-motile. In complex media, some strains grow with a sheath-like material extending past the cell poles. Spores are not observed. Ferment organic acids and a limited number of carbohydrates to acetate, hydrogen and carbon dioxide. Peptone and yeast extract are also fermented. Some amino acids (e.g. L-asparagine, L-cysteine, L-histidine, L-serine, Lthreonine or L-valine) can be used as substrates. Utilize a range of electron acceptors: thiosulfate, sulfur and Lcystine are reduced to sulfide, and crotonate is reduced to butyrate. Cellular fatty acid compositions of members of the genus include iso- $\mathrm{C}_{11: 0}$ and iso- $\mathrm{C}_{15: 0}$, and may or may not contain iso- $\mathrm{C}_{13: 0}$ and/or iso- $\mathrm{C}_{13: 0} 3-\mathrm{OH}$. The polar lipid composition contains diphosphatidylglycerol, phosphatidylglycerol, phosphatidylethanolamine, three unknown phospholipids (PL1-PL3) and four unknown aminophospholipids (PN1-PN3) and may or may not contain phospholipids PL4 and PL5. The DNA G+C content is $44-51.5 \mathrm{~mol} \%$. The type species is Anaerobaculum thermoterrenum.

\section{Description of Anaerobaculum hydrogeniformans sp. nov.}

Anaerobaculum hydrogeniformans (hy.dro.ge.ni.for'mans. N.L. n. hydrogenum hydrogen; L. part. adj. formans forming; N.L. part. adj. hydrogeniformans producing hydrogen).

Cells are $1.7-2.7 \times 0.4-0.5 \mu \mathrm{m}$. Growth occurs at $40-65{ }^{\circ} \mathrm{C}$ (optimum $55{ }^{\circ} \mathrm{C}$ ), $\mathrm{pH} 6-9$ (optimum $\mathrm{pH} 7.0$ ) and $0.8-7 \%$ $\mathrm{NaCl}$ (optimum $1 \%$ ). The DNA G $+\mathrm{C}$ content of the type strain is $46.6 \mathrm{~mol} \%$. The cellular fatty acid composition includes iso- $\mathrm{C}_{15: 0}$, iso- $\mathrm{C}_{11: 0}$, iso- $\mathrm{C}_{13: 0} 3-\mathrm{OH}$ and iso- $\mathrm{C}_{13: 0}$. The polar lipids detected are diphosphatidylglycerol, phosphatidylglycerol, phosphatidylethanolamine, unknown phospholipids PL1-PL5 and unknown aminophospholipids PN1-PN4. Sulfate, sulfite or nitrate are not reduced. Crotonate is reduced to butyrate when glucose is present. Growth occurs on D-fructose, D-glucose, maltose, Dmannose, $\alpha$-ketoglutarate, L-glutamate, malonate, pyruvate, L-tartrate, L-asparagine, Casamino acids, L-cysteine, Lhistidine, L-leucine, L-phenylalanine, L-serine, L-threonine, L-valine, inositol, inulin, tryptone and yeast extract. DArabinose, CM-cellulose, cellulose, cellobiose, D-galactose, lactose, melibiose, raffinose, D-rhamnose, sucrose, D-xylose, acetate, butyrate, citrate, fumarate, D-gluconate, lactate, L-malate, oleate, succinate, L-arginine, L-aspartate, L-glutamine, glycine, L-isoleucine, L-lysine, L-methionine, L-proline, L-tryptophan, L-tyrosine, adonitol, glycerol, dextrin, gelatin, pectin, starch and xylan do not support growth.

The type strain is $\operatorname{OS}^{\mathrm{T}}\left(=\mathrm{DSM} 22491^{\mathrm{T}}=\right.$ ATCC BAA$1850^{\mathrm{T}}$ ), isolated from oil production water collected from Alaska, USA.

Table 3. Acetate, hydrogen and methane produced by $A$. hydrogeniformans $\mathrm{OS}^{\top}, A$. thermoterrenum DSM $13490^{\top}$ and $A$. mobile DSM $13181^{\top}$

Strains were grown with D-glucose in pure culture and in co-culture with M. thermautotrophicus DSM $1053^{\mathrm{T}}$. Data for A. mobile DSM $13181^{\mathrm{T}}$ were taken from Menes \& Muxí (2002); other data were obtained in this study.

\begin{tabular}{|c|c|c|c|c|}
\hline \multirow[t]{2}{*}{ Strain } & \multirow{2}{*}{$\begin{array}{l}\text { Glucose consumed } \\
\qquad\left(\mathrm{mmol} \mathrm{l^{-1 } )}\right.\end{array}$} & \multicolumn{3}{|c|}{ Fermentation products $\left(\operatorname{mmol~l}^{-1}\right)$} \\
\hline & & $\mathbf{H}_{2}$ & Acetate & Methane \\
\hline \multicolumn{5}{|l|}{ Pure culture } \\
\hline $\mathrm{OS}_{1}^{\mathrm{T}}$ & 14.1 & 47.2 & 19.7 & - \\
\hline A. thermoterrenum DSM $13490^{\mathrm{T}}$ & 7.9 & 36.4 & 13.8 & - \\
\hline A. mobile DSM $13181^{\mathrm{T}}$ & 7.5 & 29.8 & 15.1 & - \\
\hline \multicolumn{5}{|l|}{ Co-culture } \\
\hline $\mathrm{OS} 1^{\mathrm{T}}$ & 8.4 & - & 17.6 & 8.1 \\
\hline A. thermoterrenum DSM $13490^{\mathrm{T}}$ & 8.3 & - & 16.3 & 8.7 \\
\hline A. mobile DSM $13181^{\mathrm{T}}$ & 8.5 & - & 16.9 & 8.5 \\
\hline
\end{tabular}




\section{Acknowledgements}

The authors would like to thank Dr Peter Schumann and his lab for conducting the DNA-DNA hybridization analysis and Dr Brian J. Tindall and his lab for the cellular fatty acid and polar lipid analysis. We also acknowledge Dr Hans G. Trüper for assistance with the Latin nomenclature. We are grateful to Gregory W. Strout for his assistance with the transmission electron microscopy. This work was supported by US Department of Energy contract DE-FG02-08ER64689.

\section{References}

Allen, T. D., Kraus, P. F., Lawson, P. A., Drake, G. R., Balkwill, D. L. \& Tanner, R. S. (2008). Desulfovibrio carbinoliphilus sp. nov., a benzyl alcohol-oxidizing, sulfate-reducing bacterium isolated from a gas condensate-contaminated aquifer. Int J Syst Evol Microbiol 58, 13131317.

Angenent, L. T., Karim, K., Al-Dahhan, M. H., Wrenn, B. A. \& Domiguez-Espinosa, R. (2004). Production of bioenergy and biochemicals from industrial and agricultural wastewater. Trends Biotechnol 22, 477-485.

Balch, W. E. \& Wolfe, R. S. (1976). New approach to the cultivation of methanogenic bacteria: 2-mercaptoethanesulfonic acid (HS-CoM)dependent growth of Methanobacterium ruminantium in a pressurized atmosphere. Appl Environ Microbiol 32, 781-791.

Davila-Vazquez, G., Arriaga, S., Alatriste-Mondragón, F., de LeónRodríguez, A., Rosales-Colunga, L. \& Razo-Flores, E. (2008). Fermentative biohydrogen production: trends and perspectives. Rev Environ Sci Biotechnol 7, 27-45.

De Ley, J., Cattoir, H. \& Reynaerts, A. (1970). The quantitative measurement of DNA hybridization from renaturation rates. Eur $J$ Biochem 12, 133-142.

Duncan, K. E., Gieg, L. M., Parisi, V. A., Tanner, R. S., Tringe, S. G., Bristow, J. \& Suflita, J. M. (2009). Biocorrosive thermophilic microbial communities in Alaskan North Slope oil facilities. Environ Sci Technol 43, 7977-7984.

Escara, J. F. \& Hutton, J. R. (1980). Thermal stability and renaturation of DNA in dimethyl sulfoxide solutions: acceleration of the renaturation rate. Biopolymers 19, 1315-1327.

Felsenstein, J. (1985). Confidence limits on phylogenies: an approach using the bootstrap. Evolution 39, 783-791.

Gieg, L. M., Davidova, I. A., Duncan, K. E. \& Suflita, J. M. (2010). Methanogenesis, sulfate reduction and crude oil biodegradation in hot Alaskan oilfields. Environ Microbiol 12, 3074-3086.

Gihring, T. M., Moser, D. P., Lin, L.-H., Davidson, M., Onstott, T. C., Morgan, L., Milleson, M., Kieft, T. L., Trimarco, E. \& other authors (2006). The distribution of microbial taxa in the subsurface water of the Kalahari Shield, South Africa. Geomicrobiol J 23, 415-430.

Godon, J.-J., Morinière, J., Moletta, M., Gaillac, M., Bru, V. \& Delgènes, J.-P. (2005). Rarity associated with specific ecological niches in the bacterial world: the 'Synergistes' example. Environ Microbiol 7, 213-224.

Han, S.-K. \& Shin, H.-S. (2004). Biohydrogen production by anaerobic fermentation of food waste. Int J Hydrogen Energy 29, 569-577.

Hugenholtz, P., Hooper, S. D. \& Kyrpides, N. C. (2009). Focus: Synergistetes. Environ Microbiol 11, 1327-1329.

Hungate, R. E. (1969). A roll tube method for cultivation of strict anaerobes. Methods Microbiol 3B, 117-132.

Huß, V. A. R., Festl, H. \& Schleifer, K. H. (1983). Studies on the spectrophotometric determination of DNA hybridization from renaturation rates. Syst Appl Microbiol 4, 184-192.
Jahnke, K. D. (1992). BASIC computer program for evaluation of spectroscopic DNA renaturation data from Gilford System 2600 spectrophotometer on a PC/XT/AT type personal computer. J Microbiol Methods 15, 61-73.

Johnson, J. L. (1994). Similarity analysis of DNAs. In Methods for General and Molecular Microbiology, pp. 655-682. Edited by P. Gerhardt, R. G. E. Murray, W. A. Wood \& N. R. Krieg. Washington, DC: American Society for Microbiology.

Jumas-Bilak, E., Roudière, L. \& Marchandin, H. (2009). Description of 'Synergistetes' phyl. nov. and emended description of the phylum 'Deferribacteres' and of the family Syntrophomonadaceae, phylum 'Firmicutes'. Int J Syst Evol Microbiol 59, 1028-1035.

Kapdan, I. K. \& Kargi, F. (2006). Biol-hydrogen production from waste materials. Enzyme Microb Technol 38, 569-582.

Kaster, K. M., Bonaunet, K., Berland, H., Kjeilen-Eilertsen, G. \& Brakstad, O. G. (2009). Characterisation of culture-independent and -dependent microbial communities in a high-temperature offshore chalk petroleum reservoir. Antonie van Leeuwenhoek 96, 423-439.

Kengen, S. W. M., Goorissen, H. P., Verhaart, M., Stams, A. J. M., van Niel, E. W. J. \& Claassen, P. A. M. (2009). Biological hydrogen production by anaerobic microoganisms. In Biofuels, pp. 197-221. Edited by W. Soetaert \& E. J. Vandamme. Chichester: Wiley.

Krakat, N., Schmidt, S. \& Scherer, P. (2011). Potential impact of process parameters upon the bacterial diversity in the mesophilic anaerobic digestion of beet silage. Bioresour Technol 102, 56925701.

LaPara, T. M., Nakatsu, C. H., Pantea, L. \& Alleman, J. E. (2000). Phylogenetic analysis of bacterial communities in mesophilic and thermophilic bioreactors treating pharmaceutical wastewater. Appl Environ Microbiol 66, 3951-3959.

Lee, H.-S., Salerno, M. B. \& Rittmann, B. E. (2008). Thermodynamic evaluation on $\mathrm{H}_{2}$ production in glucose fermentation. Environ Sci Technol 42, 2401-2407.

Li, C. \& Fang, H. (2007). Fermentative hydrogen production from wastewater and solid wastes by mixed cultures. Crit Rev Environ Sci Technol 37, 1-39.

Li, T., Mazéas, L., Sghir, A., Leblon, G. \& Bouchez, T. (2009). Insights into networks of functional microbes catalysing methanization of cellulose under mesophilic conditions. Environ Microbiol 11, 889-904.

Ludwig, W., Strunk, O., Westram, R., Richter, L., Meier, H., Yadhukumar, Buchner, A., Lai, T., Steppi, S. \& other authors (2004). ARB: a software environment for sequence data. Nucleic Acids Res 32, 1363-1371.

Maune, M. W. \& Tanner, R. S. (2008). Production of hydrogen from glucose or raw sewage by novel isolates of Anaerobaculum. In Abstracts of the 108th General Meeting of the American Society for Microbiology, 1-5 June 2008, Boston, MA, USA, abstract I-029. Washington, DC: American Society for Microbiology.

Menes, R. J. \& Muxí, L. (2002). Anaerobaculum mobile sp. nov., a novel anaerobic, moderately thermophilic, peptide-fermenting bacterium that uses crotonate as an electron acceptor, and emended description of the genus Anaerobaculum. Int J Syst Evol Microbiol 52, 157-164.

Mesbah, M., Premachandran, U. \& Whitman, B. (1989). Precise measurement of the $\mathrm{G}+\mathrm{C}$ content of deoxyribonucleic acid by high-performance liquid chromatography. Int J Syst Bacteriol 39, 159167.

Munson, M. A., Banerjee, A., Watson, T. F. \& Wade, W. G. (2004). Molecular analysis of the microflora associated with dental caries. J Clin Microbiol 42, 3023-3029.

Nandi, R. \& Sengupta, S. (1998). Microbial production of hydrogen: an overview. Crit Rev Microbiol 24, 61-84. 
Ohkuma, M. \& Kudo, T. (1996). Phylogenetic diversity of the intestinal bacterial community in the termite Reticulitermes speratus. Appl Environ Microbiol 62, 461-468.

Olsen, G. J., Matsuda, H., Hagstrom, R. \& Overbeek, R. (1994). fastDNAmL: a tool for construction of phylogenetic trees of DNA sequences using maximum likelihood. Comput Appl Biosci 10, 41-48.

Orphan, V. J., Taylor, L. T., Hafenbradl, D. \& Delong, E. F. (2000). Culture-dependent and culture-independent characterization of microbial assemblages associated with high-temperature petroleum reservoirs. Appl Environ Microbiol 66, 700-711.

Rees, G. N., Patel, B. K., Grassia, G. S. \& Sheehy, A. J. (1997). Anaerobaculum thermoterrenum gen. nov., sp. nov., a novel, thermophilic bacterium which ferments citrate. Int J Syst Bacteriol 47, 150-154.

Sasaki, K., Haruta, S., Tatara, M., Yamazawa, A., Ueno, Y., Ishii, M. \& Igarashi, Y. (2006). Microbial community in methanogenic packedbed reactor successfully operating at short hydraulic retention time. J Biosci Bioeng 101, 271-273.

Sasaki, K., Haruta, S., Ueno, Y., Ishii, M. \& Igarashi, Y. (2007). Microbial population in the biomass adhering to supporting material in a packed-bed reactor degrading organic solid waste. Appl Microbiol Biotechnol 75, 941-952.

Schröder, C., Selig, M. \& Schönheit, P. (1994). Glucose fermentation to acetate, $\mathrm{CO}_{2}$ and $\mathrm{H}_{2}$ in the anaerobic hyperthermophilic eubacterium Thermotoga maritima: involvement of the EmbdenMeyerhof pathway. Arch Microbiol 161, 460-470.

Stackebrandt, E. \& Ebers, J. (2006). Taxonomic parameters revisited: tarnished gold standards. Microbiol Today 33, 152-155.

Tanner, R. S. (2007). Cultivation of bacteria and fungi. In Manual of Environmental Microbiology, 3rd edn, pp. 69-78. Edited by C. J. Hurst,
R. L. Crawford, A. L. Mills, J. L. Garland, L. D. Stetzenbach \& D. A. Lipson. Washington, DC: American Society for Microbiology.

Thauer, R. K., Jungermann, K. \& Decker, K. (1977). Energy conservation in chemotrophic anaerobic bacteria. Bacteriol Rev 41, 100-180.

US Department of Energy (2007). Hydrogen, Fuel Cells, and Infrastructure Technologies Program: Multi-year Research, Development and Demonstration Plan. Washington, DC: US Department of Energy.

van der Kraan, G. M., Bruining, J., Lomans, B. P., van Loosdrecht, M. C. M. \& Muyzer, G. (2010). Microbial diversity of an oil-water processing site and its associated oil field: the possible role of microorganisms as information carriers from oil-associated environments. FEMS Microbiol Ecol 71, 428-443.

van Niel, E. W. J., Budde, M. A. W., de Haas, G. G., van der Wal, F. J., Claassen, P. A. M. \& Stams, A. J. M. (2002). Distinctive properties of high hydrogen producing extreme thermophiles, Caldicellulosiruptor saccharolyticus and Thermotoga elfii. Int J Hydrogen Energy 27, 1391-1398.

Vartoukian, S. R., Palmer, R. M. \& Wade, W. G. (2007). The division "Synergistes". Anaerobe 13, 99-106.

Voordouw, G., Armstrong, S. M., Reimer, M. F., Fouts, B., Telang, A. J., Shen, Y. \& Gevertz, D. (1996). Characterization of 16S rRNA genes from oil field microbial communities indicates the presence of a variety of sulfate-reducing, fermentative, and sulfide-oxidizing bacteria. Appl Environ Microbiol 62, 1623-1629.

Winter, J., Braun, E. \& Zabel, H.-P. (1987). Acetomicrobium faecalis sp. nov., a strictly anaerobic bacterium from sewage sludge, producing ethanol from pentoses. Syst Appl Microbiol 9, 71-76.

Wu, J.-H., Liu, W.-T., Tseng, I. C. \& Cheng, S.-S. (2001). Characterization of microbial consortia in a terephthalate-degrading anaerobic granular sludge system. Microbiology 147, 373-382. 